は加成性が成立せす，且つ異性體の間には數 $\mathrm{kcul} / \mathrm{mol}$ の差が西る事が分つた。この原因は炭素原

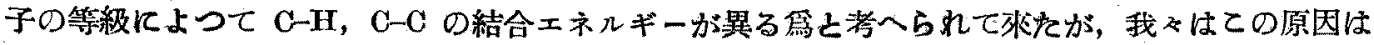
直接には結合して居ない原子間の相互作用に上るもので， C-H， C-C の結合ェネルギーは近似的

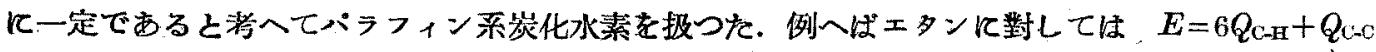

・ $+\Sigma J$ 之表はす. 此處に $J$ は種くの距離にある非結合の $\mathrm{C}-\mathrm{C}, \mathrm{O}-\mathrm{H}, \mathrm{H}-\mathrm{H}$ の相互作用である。

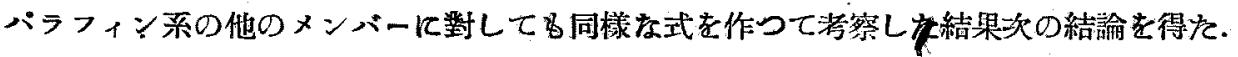

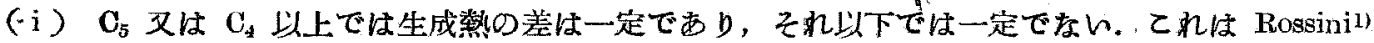
の賽驗事賽を說明して居る。

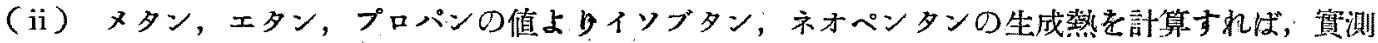
己極めてよく一政する。郎ち正パラフィンの值でィソパラフィンの值をよく說明し得る.

(iii） 2,2-二メチルブタン及び正パラフィンより他の多くの（んくつかの第三級及び第四級䈐素原 子を含む)イソパラフィンの生成熱を計算すれば實測とよく一致する.

(iv） 正ブタン, 正ペンタンの中間型とトランス型とのェネルギー差は夫タ 2-メチルブタン, 2-メ チルペンタン等を用ひて計算すると网者とる $0.7 \mathrm{kcal} / \mathrm{mol}$ となり, 此熱から求められた $0.8 \mathrm{kcal}$ mol'2) と極めてよく一致する。

(v) 種々の距離にある $\mathrm{C}-\mathrm{C}, \mathrm{C}-\mathrm{H}, \mathrm{H}-\mathrm{H}$ のボテンシャルエネルギー $\boldsymbol{J}$ の間に簡單を關係を求 める事が出來，てれはをと他の計算に用しることが出來る。

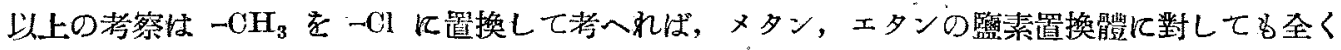
同樣に用いる事が出隶る. 現存のデータを用いた結果は，上の临點に對して满足な結果が得られ， 特に 1.2-二クロルエタンの中間型, トランス型のエネルギー差は約 $1.0 \mathrm{kenl} / \mathrm{mol}$ となり，真测 $1.2 \mathrm{kcal} / \mathrm{mol}^{3)}$ とよく一致する. 然し鹽素置換體の生成熱は䁈湘值の誤差が大をんので詳細な論議 は今後にまつ可をものと思はれる。

以上に上り生成熱のデータから見て場合，分子冈ポテンシャルに於ては非結合原子間の相互作用 が重要を役割りをなして居るものと考へられる。

（昭和二十二年七月一日受領）（名古屋帝國大學理學部化學数室）

[交獣]

1) F.D. Rossini: Chem. Rev., 27(1940), 1; Rossini: J. Research Natl. Bur. Stand., 13(1934), 29.

2). K.S. Pitzer: Chem. Rev., 27 (1940) 39.

3) 没渗, 水島, 森野: 本誌, 63 (1942) 1131 .

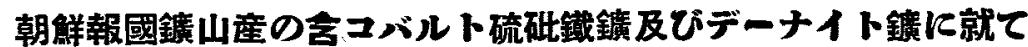

On Cobalt-bearing Arsenopyrite and Denaite from Hökoku Mine, Korea.

$$
\text { 田中, 信 行 }
$$

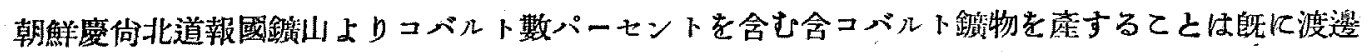

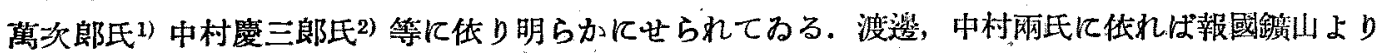

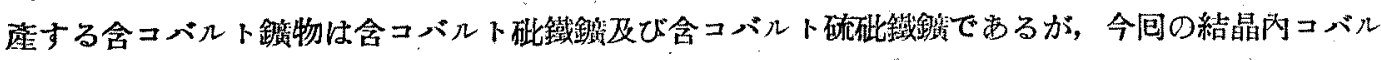

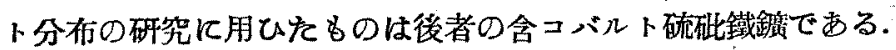

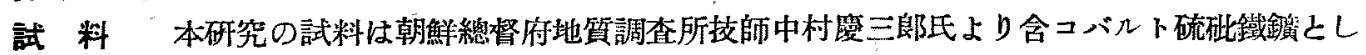

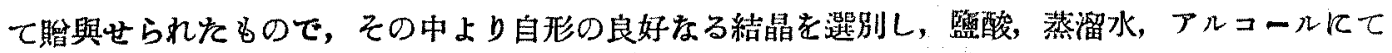


洗條し充分に乾燥して分析試料とした.

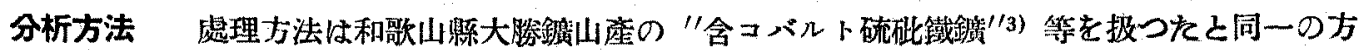

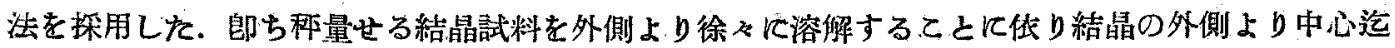

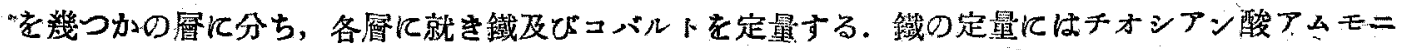

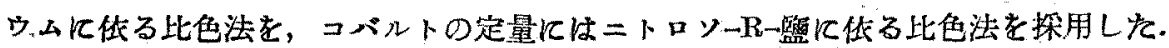

分析結果 試料 No. 3, No.4 No. 5 の3 個の結晶に就き上述の方法を用ひて結晶內コバルト分 布を求めた. 各結晶の重量はそれぞれ $19.212 \mathrm{mg}, 9.125 \mathrm{mg}$ 及び $10.480 \mathrm{mg}$ である. 試料を立方. 體と假定して求めた各屏の中心からの距離とそのコバルト含量を第 1 圆に圖示する. 又各結晶の鐵

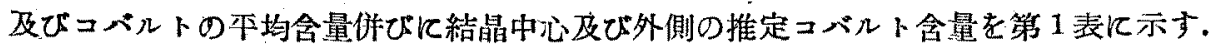

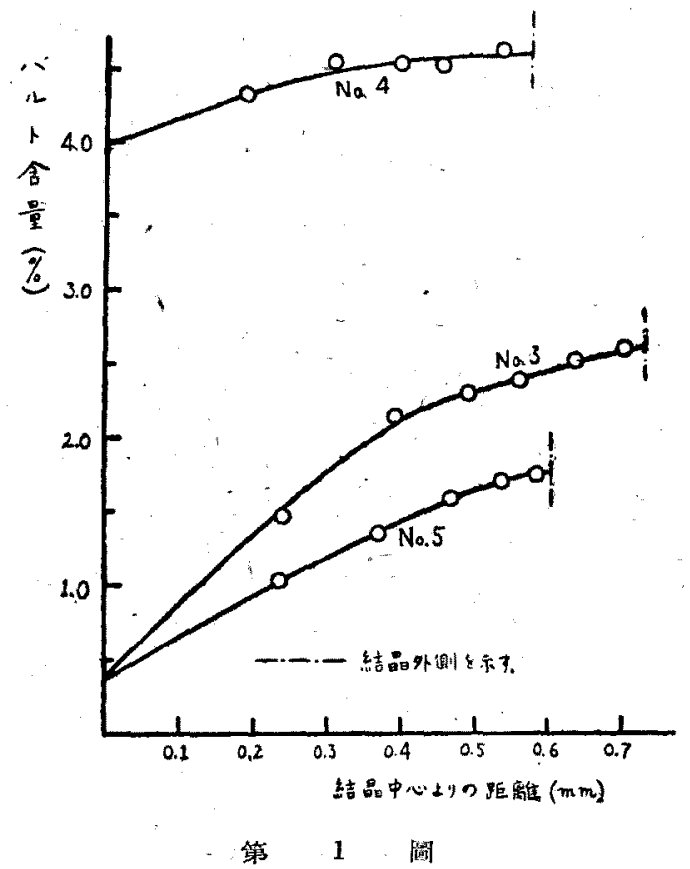

\begin{tabular}{|c|c|c|c|c|}
\hline \multirow[t]{2}{*}{ 試料悉歡 } & \multicolumn{2}{|c|}{ 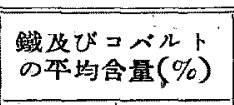 } & \multicolumn{2}{|c|}{ 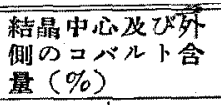 } \\
\hline & 鐡 & エベルト & 中 心 & 外 側 \\
\hline No. 3 & 31.1 & 2.34 & $0.3_{5}$ & $2.6_{5}$ \\
\hline No. 4 & 29.8 & 4.60 & 4.0 & 4.65 \\
\hline No. 5 & 31.4 & 1.53 & $0.3_{5}$ & $1.7_{5}$ \\
\hline
\end{tabular}

第 1 表から判る如く，本鑛物の結晶全體の組 成は試料 No. 3 及び No.5 亿於ては含コバルト 硫䂤鐵鏡，試料 No.4 亿於てはデーナイト鋠に 相當する.しかしながら何れの結晶に於てる結 晶內に於てコバルト含量は不均一性を示し，中 心上り外側に移るに從ひ漸次增加の傾向を示し

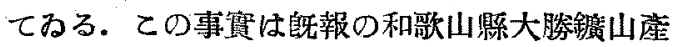

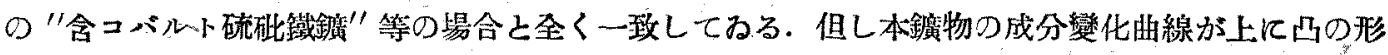
を示すこと，郎ち結晶中心よりの距離が增加すると共にコバルト含量の增加が紘慢となる事賽は從 來の結果之全く異なる點で，乙れは本鐄床の成因に由來するるのではいかと思はれる。

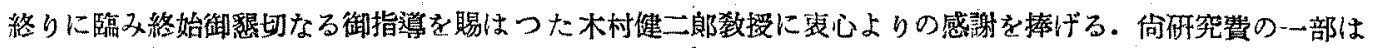
學術研究會議第二部稀元素研究班より支辨せられたことを記ず.

\section{（昭和ニ十二年 $\mathrm{A}$ 月十七日受領）（果京帝國大學理學部化學教空）}

[交獻]

1) 液邊萬次郎：岩磁， 30 (1943)

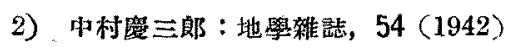

3）田中信行：本踋，67 (1946), 70 . 